\title{
To the history of the method of transosseous osteosynthesis in the Middle Urals
}

\author{
S.M. Kutepov, S.V. Gulnazarova
}

Ural State Medical University, Ekaterinburg, Russian Federation

\begin{abstract}
Background The article reviews the history of the study, development and application of the method of transosseous osteosynthesis in the Middle Urals. G.A. Ilizarov first presented his device and the results of its use in fracture repair at a meeting of the Trauma and Orthopedic Scientific Society in Sverdlovsk in December 1952. The report was met with great interest. Prof. F.R. Bogdanov invited him to conduct research on bone regeneration during compression osteosynthesis at the Ural Research Institute for Trauma and Orthopaedics. The work initiated by G.A. Ilizarov and V.I. Stetsula gave rise to a large and longterm research on transosseous osteosynthesis at the Institute. The study focused on regeneration of bone, muscles, blood vessels and nerves, development and justification of compression-distraction osteosynthesis in fractures, limb shortening, nonunions, bone deformities, severe injuries to the pelvis, spine and spinal cord. Basic research was conducted to explore the role of the blood system and immune reactions involved in bone formation during limb lengthening. Material and methods Databases of scientific works and technical solutions registered with authorship certificates and patents of the USSR and the Russian Federation by fellow workers of the VOSKHITO, SNIITO, the Ural Research Institute for Trauma and Orthopaedics, the holdings of the Institute's scientific archive facility were used for the article. The search depth is 68 years. Results The Ural V.D. Chaklin Research Institute for Trauma and Orthopaedics has been studying and using the method of G.A. Ilizarov for many years and has made a significant contribution through theoretical rationale, development of new technologies of transosseous osteosynthesis, introduction and spread of the techniques over the vast territory of the Middle Urals and neighboring regions. Conclusion Despite the fact that in the recent years, transosseous osteosynthesis has to a certain extent been replaced in Russia by modern techniques with constructs of internal osteosynthesis, but there is no alternative to the method of G.A. Ilizarov in the treatment of gunshot wounds, open fractures, polytrauma, extensive bone defects, achondroplasia and many other disorders of the musculoskeletal system.
\end{abstract}

Keywords: Ilizarov, founder, transosseous osteosynthesis, trauma and orthopaedics

\section{INTRODUCTION}

The method of compression-distraction osteosynthesis is inextricably interwoven with the name of the creator Gavriil Abramovich Ilizarov who first reported on A new principle of osteosynthesis and elongation of the lower limbs using rings and wires on December 10, 1952 at a meeting of the Sverdlovsk Scientific Medical Trauma and Orthopaedic Society and received the author's certificate No. 98471 for his invention $A$ method for healing broken bones and a frame for the performance in 1954 [1]. The method immediately attracted the attention of orthopaedic and trauma surgeons due to the favorable outcomes seen in patients with bone pathology. Theoretical studies on the regularities of bone formation during compression with the author's frame were unavailable due to the novelty of the method and there was no knowledge about the amount of compression forces to be applied, indications and contraindications to the new technology, adequate postoperative care and many other issues. Professor F.R. Bogdanov, Director of the Ural Institute of Trauma and Orthopaedics (UITO), initiated experimental research to present a theoretical argument for compression osteosynthesis. A research group headed by V.I. Stetsula, Ph.D., in charge of the pathanatomic laboratory of the Institute was established for this purpose in 1956 to include G.A. Ilizarov and young researchers of UITO V.P. Rzhavina, I.A. Staheev, N.V. Novitskaya. The first experimental canine study was performed by G.A. Ilizarov and V.P. Rzhavina in 1956-1958 to explore consolidation in compression arthrodesis of the knee joint [2]. The researchers demonstrated the possibility of achieving primary bone healing of the entire bonesaw area as early as 8-10 days after the operation maintaining stiffness at the docking site with the frame on. The creation of permanent immobility at the site was found to provide optimal conditions for osteogenesis and primary bone healing with a small volume of regeneration that significantly reduced the time of consolidation during joint arthrodesis [3]. The results of this study were presented at the IVth Ukranian Trauma and Orthopedic Meeting in 1959 and won a high appraisal. 


\section{MATERIAL AND METHODS}

Databases of scientific works and technical solutions registered with authorship certificates and patents of the USSR and the Russian Federation by fellow workers of the VOSKHITO, SNIITO, the Ural
Research Institute for Trauma and Orthopaedics, the holdings of the Institute's scientific archive facility were used for the article. The search depth is 68 years.

\section{RESULTS AND DISCUSSION}

Complex studies were organized at VOSKHITO under the leadership of V.I. Stetsula in 1959 to explore compression osteosynthesis experimentally and clinically. I.A. Staheev was assigned to experimentally investigate healing of auto-, homo- and heterografts in complete and permanent immobility during compression arthrodesis of the knee joint. Healing of large grafts occupying the entire bone cross-section with the femoral and tibial epimetaphyses showed the possibility of consolidation of the graft and the bone bed as early as $2-3$ weeks after surgery $[4,5]$. Based on the findings of the series large homografts were applied in clinical scenario to address limb shortening during joint arthrodesis. Theoretical studies of transosseous compression osteosynthesis involved investigations of consolidation of long bone fractures and nonunions. The experimental and clinical study performed by N.V. Novitskaya [6] showed that consolidation of long bone fractures and nonunions could heal if the bone was fixed rigidly with the help of the transosseous apparatus. The findings exhibited the necessity to preserve blood supply in nonunited bone [7], the importance of controlling compression forces during treatment and indications to open and closed compression osteosynthesis of long bone nonunions.

Experimental series on bone regeneration in compression osteosynthesis were summarized by V.I. Stetsula in 1965. Based on the morphological study of the comprehensive and unique experimental material, he justified and formulated the basic principles of compression osteosynthesis. V.I. Stetsula showed that steady pressure did not cause any reaction in the bones and did not have any stimulating or depressing effect on reparative reactions. Primary bone healing was noted to develop with rigid bone fixation provided within a short period of time and primarily depend on the restoration of local blood supply. V. I. Stetsula detected that blood supply at the terminal portions of nonunion was similar to that of the cancellous bone identifying the active nature of reparative osteogenesis [8]. The comprehensive study of bone regeneration showed the advantages of compression osteosynthesis that provided conditions for the normalization of local blood supply and activation of bone formation to occur within a short period of time as primary bone consolidation through rigid bone fixation. The theoretical studies significantly contributed to the introduction of Ilizarov transosseous compression osteosynthesis into clinical practice.

VOSKHITO was renamed the Sverdlovsk Research Institute of Reconstructive Surgery, Trauma and Orthopaedics (SRIRSTO), Ministry of Health of the Russian Federation in 1958. In the $70-80$ years of the twentieth century, one of the main scientific trends of the research of the Institute was the study of distraction osteosynthesis experimentally and clinically. Experimental studies showed that stable Ilizarov fixation during distraction osteosynthesis facilitated the diastasis between bone fragments being replaced by desmal regenerate bone to be followed by restructuring into the diaphyseal bone. Reparative regeneration appeared to be dependent on such factors as the distraction rate, stable bone fixation, the elongation site (metaphysis or diaphysis), the extent of preserved blood circulation in the bone. The process of distraction osteosynthesis was associated with such fundamental questions as what should be the rational lengthening rate, the latency period after surgery, the amount of one-stage limb lengthening, etc. E.T. Nikitenko [9] reported experimental latency period for distraction in the metaphysis and diaphysis, the optimal daily distraction rate, the strength characteristics of the newly formed bone and the optimal timing for the functional loading.

Experimental studies of regeneration of pathologically altered bone were performed on different canine models of nonunions [10]. Desmal bone was shown to develop during distraction of nonunion and bone lengthening after osteotomy. The possibility of replacing the interfragmental layer with bone tissue was determined by the type of nonunion (hyperplastic or hypoplastic), the nature of pathological restructuring at the ends of the fragments (osteoporosis, osteosclerosis) and stable fixation of the regenerate bone and subsequent restructuring. Clinical recommendations were developed for the types of surgical intervention, the latency period and the optimal distraction rate depending on the baseline pathological restruycturing of the nonunion $[11,12]$. The findings 
facilitated introduction of the distraction method into clinical practice to treat patients with nonunions.

A clinical study exploring treatment of children with lower limb shortening focused on the use of distraction osteosynthesis, indications and contraindications to bone lengthening, amount of length to be gained, surgical strategy and recommendations to prevent errors in the treatment of femoral and tibial shortening [13]. Clinical and experimental study of pediatric limb lengthening using distraction epiphyseolysis was performed at that time to identify specific features of reparative bone regeneration, age-related indications to the method, its effect on the growth of the elongated bone and adjacent joints [14]. Generalizing series of V.P. Shtin [15-18] were based on a thorough morphological analysis of the extensive experimental material and had an important theoretical significance for distraction osteosynthesis reporting specific features of bone regeneration at all stages of limb lengthening and the restructuring phase, introducing the term "growth zone" identifying its role in distraction regeneration, describing organotypic restructuring of the newly formed bone and providing general biological justification of the physiology of bone formation during distraction based on the analysis of changes in the apophysis of the bones of young animals during the growth $[16,17]$. These studies were very important for trauma surgeons enriching significantly their knowledge of distraction osteosynthesis and contributing to its introduction into medical practice $[18,19]$.

The studies of the distraction method performed in the following years emphasized on the theoretical aspects of bifocal distraction osteosynthesis including the reparative bone response, regenerate restructuring $[20,21]$, regeneration of muscles and tendons [22] and the efferent neurons of the reflex arc [23, 24]. In addition to clinical problems associated with the introduction of distraction osteosynthesis, the Institute's staff conducted experimental basic research to explore the role of the blood system and its components in bone formation during limb lengthening $[25,26]$, the immunological mechanisms of regulation of recovery in distraction osteosynthesis [27 ].

A new specialized clinical department was established at the Institute in January 1981 to treat patients with bone and joint diseases using compression-distraction method. Theoretical studies on various aspects of transosseous osteosynthesis conducted earlier facilitated management of fractures, nonunions, old dislocations, fracture-dislocations, contractures of major joints, deformity correction, restoration of the anatomical length and shape of bone segments at the department.
The researchers developed new methods of treating musculoskeletal pathology using compression and distraction techniques supported by 53 author's certificates and patents. Assessment of the individual capacities of a patient with nonunions of long bones was part of the research performed at the department aimed at restoration of the normal bone structure at the site of injury. Prognostic algorithms were developed for the preoperative stage and during treatment to identify patients with a possible unfavorable outcome. Step-by-step monitoring based on prognostic findings allowed development of a treatment strategy for a particular patient and its timely adjustment to reduce postoperative failure rate $[28,29]$.

Transosseous osteosynthesis as the basic technique used at the department was practical for challenging clinical scenarios using optimization techniques for Ilizarov patients. Those included new highly sensitive tests for assessing the dynamics of reparative processes, the use of pharmacological agents [30] and physical methods for improving osteogenesis [31], the use of percutaneous fixators with a nanostructured osteoinductive coating [32] and others. A variety of optimization techniques for the compressiondistraction method could facilitate reduced length of treatment, decreased severity of bone resorption at pin sites maintaining stable fixation and patient compliance as a very important tool for the successful outcome. Many-year experience of the clinic in the treatment of osteoporotic patients using the method of transosseous osteosynthesis has shown that the Ilizarov method is the best treatment option for any bone pathology regardless of the type of osteoporosis. Transosseous osteosynthesis technologies with less traumatic bone surgery can provide a high percentage of recovery for osteoporotic patients suffering from bone and joint diseases [30, 31, 32].

The history of transosseous osteosynthesis applied to pelvic bones in SRIRSTO dates back to the 70s of the twentieth century, when N. A. Serebrennikov offered a device for pelvic reduction and fixation [33]. However, the design of the frame failed to provide stable fixation during the entire period of pelvic healing and was not widely used in clinical practice. A new device for pelvic bones was devised in 1989 by a group of authors led by Director of the Institute S.M. Kutepov [34]. The device had a circular external support and could be used for reduction of the vertical displacements of the broken pelvic half with the rods fixed to the posterior pelvis providing stable fixation for the entire period of consolidation [35, 36, 37]. Pelvic applications were further developed by A.V. Runkov and co-authors who 
offered an updated design of the device [38]. New fixation and transosseous components were developed for the device with original variants of the placement, improved system of reduction units and the modular principle of building an external support. The new device with the unique reduction capacity could be used for the treatment of most severe posttraumatic pelvic deformities including bilateral cases. Step-by-step correction of pelvic ring deformities was performed [39, $40,41]$ with such original procedures as percutaneous osteotomy of the posterior and anterior pelvis and bone-plastic reconstructions developed and introduced into clinical practice. Extensive Institute's experience in the treatment of pelvic injuries and deformities was summarized in the book on transosseous osteosynthesis published abroad and edited by Professor L.N. Solomin $[42,44]$. In 2010 the team of authors was awarded with the Foundation for High Medical Technologies Diploma established in memory of Academician G.A. Ilizarov for their great contribution to the improvement and implementation of technologies of transosseous osteosynthesis in the treatment of pelvic injuries and posttraumatic conditions. Nowadays the Ural Institute of Traumatology and Orthopedics named after V.D. Chaklin continues to develop new technologies for the treatment of complex multiplanar pelvic deformities and combined minimally invasive procedures for the fixation.

Spinal surgery have long remained uninvolved with Ilizarov external fixation despite the fact that the ideas of G.A. Ilizarov have long been widely used in trauma and orthopaedics. Since 1992, the team of authors at UITO has been conducting anatomotopographic research of the thoracic and lumbosacral spine. Elastic modulus and the ultimate strength of the spinal cancellous bone were experimentally determined at destruction with radiometry performed for the lower thoracic and lumbar spine. Based on these data the authors specified the parameters for the rods of spinal transpedicular fixation and devised the original shape of the basic support plate and auxiliary components of the external fixation device [45-48]. New knowledge about the interaction at the "rod-bone" boundary allowed us to extend the possibilities of the spinal rod fixation and develop the methods of closed, less traumatic, controlled correction of spinal deformities in three planes with a new approach to the spinal deformity realignment for closed decompression of the spinal cord and cauda equina roots. Osteosynthesis with the original external fixation device proved to be a reliable way to stabilize the spine for the entire period necessary for the formation of new structural bonds of the injured spine. New treatment methods for spinal cord injuries, old spinal fractures and diseases have shown to be very effective [49-53]. External fixation of the spine significantly reduced the time of consolidation after surgical treatment and reduced disability rates [54-57]. New treatment method developed at the spinal clinic to address spinal injuries and diseases were covered by 13 patents of the Russian Federation, and the research team was awarded the prize of the Academician G. A. Ilizarov Foundation for a series of works in the field of science and technology "Development of external fixation devices and new methods of treatment for injuries and diseases of the spine and the spinal cord". In addition to that, new technologies for the treatment of spinal diseases and injuries have been awarded with multiple diplomas for the best innovative projects in the field of intellectual property in Russia. Theoretical studies on various theoretical and clinical aspects of bone formation during transosseous compression osteosynthesis have been performed at the Institute since 1956 (V.I. Stetsula, G.A. Ilizarov, V.P. Rzhavina, 1959) and were included in 16 doctoral and $32 \mathrm{PhD}$ theses, 22 monographs. We can suggest that these works along with the contribution from many other authors have significantly extended Ilizarov applications and yielded more insight into the "Ilizarov Effect" of general biological response of tissues to gradual distraction as growth and regeneration $[58,59]$.

\section{CONCLUSION}

Although transosseous osteosynthesis techniques have been replaced in some ways by modern plate and nail designs in Russia in recent years there is no alternative to the Ilizarov method in the treatment of gunshot wounds, open fractures, polytrauma, extensive bone defects, achondroplasia and many other musculoskeletal disorders. Reconstructive surgery of the bones and joints based on the laws of nature formulated as the "Ilizarov Effect" is known all over the world. Transosseous osteosynthesis can be used as a standalone method of treatment and also be combined with other technologies that extend the possibilities of the outstanding method to address the challenging clinical scenarios when other methods of treatment fail to provide a successful result.

No competing interests were disclosed. The authors received no specific funding for this work. 


\section{REFERENCES}

1. Ilizarov G.A. Sposob srashchivaniia kostei pri perelomakh i apparat dlia osushchestvleniia etogo sposoba [The method for bone fusion in case of factures and the device for implementing this method]. Author's license no. 98471 SSSR, 102/17-762/447962, 1952. (in Russian)

2. Stetsula V.I., Ilizarov G.A. Regeneratsiia kostnoi tkani pervichnym natiazheniem pri artrodeze kolennogo sustava v eksperimente [Bone tissue regeneration with primary intention for the knee arthrodesis expermentally]. Trudy IV Sezda travmatologov i ortopedov Ukrainy [Proceedings of the IV Congress of traumatologists and orthopedists of the Ukraine]. Kharkov, 17-18 June, 1959. Kiev, Gos. Med. Izd-vo USSR, 1960, pp. 205-208. (in Russian)

3. Ilizarov G.A., Stetsula V.I., Rzhavina V.P. O regeneratsii kosti v usloviiakh polnoi i nepolnoi immobilizatsii [On bone regeneration under conditions of complete and incomplete immobilization]. Vestnik Khirurgii im. I.I. Grekova, 1961, no. 4, pp. 6-15. (in Russian)

4. Stakheev I.A., Stetsula V.I. O prizhivlenii auto- i gomotransplantatov pervichnym natiazheniem [On the engraftment of auto- and homografts with primary intention]. Trudy mezhobl. nauch.-prakt. konf., posviashchennoi kompressionnomu osteosintezu, sustavnoi patologii $i$ voprosam klinicheskoi travmatologii Sverdlovskogo NII Travmatologii i Ortopedii "Voprosy Vosstanovitelnoi Khirurgii, Travmatologii $i$ Ortopedii", 1961 [Proceedings of the Interregional Scientific-Practical Conference devoted to Compression Osteosynthesis, Articular Pathology and Problems of Clinical Traumatology of the Sverdlovsk Scientific Research Institute of Traumatology and Orthopedics "Problems of Restorative Surgery, Traumatology and Orthopedics”, 1961], Sverdlovsk, 1962, vol. 8, pp. 32-35. (in Russian)

5. Stetsula V.I., Stakheev I.A. Rol kontakta i davleniia v reparativnoi regeneratsii kosti [Role of contact and pressure in bone reparative regeneration]. Voprosy Vosstanovitelnoi Khirurgii, Travmatologii i Ortopedii: sb. statei, Sverdlovsk, 1964, vol. 9, pp. 448-450. (in Russian)

6. Stetsula V.I., Novitskaia N.V. Regeneratsiia kosti pri kompressionnom osteosinteze diafiza v eksperimente [Bone regeneration in compression osteosynthesis of the shaft experimentally]. Trudy mezhobl. nauch.-prakt. konf., posviashchennoi kompressionnomu osteosintezu, sustavnoi patologii $i$ voprosam klinicheskoi travmatologii Sverdlovskogo NII Travmatologii i Ortopedii "Voprosy Vosstanovitelnoi Khirurgii, Travmatologii $i$ Ortopedii", 1961 [Proceedings of the Interregional Scientific-Practical Conference devoted to Compression Osteosynthesis, Articular Pathology and Problems of Clinical Traumatology of the Sverdlovsk Scientific Research Institute of Traumatology and Orthopedics "Problems of Restorative Surgery, Traumatology and Orthopedics”, 1961], Sverdlovsk, 1962, vol. 8, pp. 44-49. (in Russian)

7. Stetsula V.I. novoobrazovanii kapilliarov pri reparativnoi regeneratsii kostei [On new formation of capillaries for reparative bone regeneration]. Materialy Konferentsii, posviashchennoi 100-letiiu Kafedry Gistologii VMA im. S.M. Kirova [Proceedings of the Conference devoted to $100^{\text {th }}$ Anniversary of the Department of Histology of the Kirov Military Medical Academy. L., 19680, pp. 204-205. (in Russian)

8. Stetsula V.I., Veklich V.V. Osnovy upravliaemogo chreskostnogo osteosinteza [Fundamentals of guided transosseous osteosynthesis]. M., Meditsina, 2003, 220 p. (in Russian)

9. Shtin V.P, Nikitenko E.T. Morfologicheskie dannye k obosnovaniiu sroka nachala distraktsii pri operativnom udlinenie goleni v eksperimente [Morphological data to substantiate the timing of distraction onset during surgical lengthening of the leg experimentally]. Ortopediia, Travmatologiia i Protezirovanie, 1974, no. 5, pp. 48-51. (in Russian)

10. Shtin V.P., Giulnazarova S.V. Morfogenez mezhotlomkovoi tkani na rannikh etapakh distraktsii gipertroficheskikh psevdoartrozov (eksperimentalnomorfologicheskoe issledovanie) [Morphogenesis of interfragmental tissue at the early stages of distraction of hypertrophic pseudoarthroses (an experimental-and-morphological study)]. Ortopediia, Travmatologiia i Protezirovanie, 1985, no. 9, pp. 5-9. (in Russian)

11. Giulnazarova S.V. Lechenie «boltaiushchikhsia» psevdoartrozov s odnovremennym udlineniem na urovne patologicheskogo ochaga (eksperimentalnoe issledovanie) [Treatment of "flail" pseudoarthroses with simultaneous lengthening at the level of the pathological focus (an experimental study)]. Ortopediia, Travmatologiia i Protezirovanie, 1978, no. 11, pp. 31-34. (in Russian)

12. Giulnazarova S.V., Shtin V.P. Lechenie lozhnykh sustavov. Teoriia i praktika metoda distraktsii [Treatment of pseudoarthroses. Theory and practice of the method of distraction]. Ekaterinburg, Izd-vo Ural. Un-ta, 1992, 143 p. (in Russian)

13. Fedotova R.G. K metodike operativnogo udlineniia vrozhdenno-ukorochennoi konechnosti u detei [Towards the technique of surgical lengthening of a congenitally shortened limb in children]. Ortopediia, Travmatologiia i Protezirovanie, 1970, no. 12, pp. 18-22. (in Russian)

14. Gorbunova Z.I., compiler. Pokazaniia i taktika vedeniia bolnykh pri udalenii goleni metodom distraktsionnogo epifizeoliza po Ilizarovu: metod. rek. [Indications and tactics of managing patients when lengthening the leg by the method of distraction epiphysiolysis according to Ilizarov: a technique manual]. MZ RSFSR, SB VKNTs VTiO. Sverdlovsk, 1989, 17 p. (in Russian)

15. Shtin V.P., Mikhailova L.N. Ob osobennostiakh regeneratsii pri distraktsii kostnykh otlomkov [On the special features of regeneration in case of distraction of bone fragments]. Arkhiv Patologii, 1978, no. 8, pp. 50-56. (in Russian)

16. Lavrishcheva G.I., Shtin V.P. Osobennosti reparativnykh protsessov pri distraktsionnom osteosinteze [Special features of reparative processes in distraction osteosynthesis]. Trudy 3-go Vsesoiuznogo Sezda Travmatologov-ortopedov. Moskva, 13-15 Maia, 1975 [Proceedings of the ${ }^{\text {rd }}$ All-Union Congress of Traumatologists-orthopedists. Moscow, May 13-15, 1975]. M., TsITO, 1976, pp. 179-184. (in Russian)

17. Mikhailova L.N., Shtin V.P. Elektronno-mikroskopicheskoe issledovanie osobennostei differentsiatsii skeletogennoi tkani pri distraktsionnom osteosinteze [An eletrone-microscopic study of the special features of differentiation of skeletogenous tissue in distraction osteosynthesis]. Arkhiv Patologii, 1979, no. 5, pp. 55-63. (in Russian)

18. Stetsula V.I., Lavrishcheva G.I., Shtin V.P., Mikhailova L.N. Biologicheskie aspekty udlineniia konechnostei [Biological aspects of limb lengthening]. Ortopediia, Travmatologiia i Protezirovanie, 1984, no. 9, pp. 21-26. (in Russian)

19. Ilizarov G.A., Lediaev V.I., Shtin V.P. Techenie reparativnoi regeneratsii kompaktnoi kosti pri distraktsionnom osteosinteze v razlichnykh usloviiakh fiksatsii kostnykh otlomkov (eksperimentalnoe issledovanie) [The course of reparative regeneration of compact bone in distraction osteosynthesis under various conditions of the fixation of bone fragments (an experimental study)]. Eksperimentalnaia Khirurgiia i Anesteziologiia, 1966, no. 6, pp. 3-12. (in Russian)

20. Shtin V.P., Kochutina L.N., Reutov A.I. Otsenka vozmozhnostei kosteobrazovaniia i sokhraneniia gistostruktury myshts pri bilokalnom distraktsionnom osteosinteze [Evaluatiion of the possibilities of bone formation and muscle histostructure preservation in bilocal distraction osteosynthesis]. Materialy 3-go Mezhdunarodnogo Seminara po usovershenstvovaniiu apparatov i metodov vneshnei fiksatsii "Apparaty i Metody Vneshnei Fiksatsii v Travmatologii $i$ Ortopedii" [Proceedings of the $3^{\text {rd }}$ International Workshop on the Improvement of External Fixators and Methods of External Fixation "Devices and Methods of External Fixation in Traumatology and Orthopaedics"]. Riga, 1989, pp. 258. (in Russian)

21. Reutov A.I. Sravnitelnaia kharakteristika metodov mono- i bilokalnogo distraktsionnogo osteosinteza po G.A. Ilizarovu (eksperimentalnoe issledovanie) [Comparative characteristics of the techniques of mono- and bifocal distraction osteosynthesis according to G.A. Ilizarov (experimental study)]. Genij Ortopedii, 2002, no. 3, pp. 108-115. (in Russian)

22. Kochutina L.N., Reutov A.I. Reaktivnost skeletnoi myshechnoi tkani i regeneratsiia kosti pri bolshikh odnoetapnykh udlineniiakh metodom monolokalnogo distraktsionnogo osteosinteza po Ilizarovu [Reactivity of skeletal muscle tissue and bone regeneration in large one-stage lengthenings by the method of monolocal distraction osteosynthesis according to Ilizarov]. Tez. dokl. mezhdunar. konf. "Eksperimentalnoteoreticheskie i Klinicheskie Aspekty razrabatyvaemogo v KNIIEKOT metoda chreskostnogo osteosinteza", 3-5 sentiabria 1986 g. [Proceedings of the International Conference "Experimental-theoretical and Clinical Aspects of the Transosseous Osteosynthesis method, being developed in KSRIECOT", September 3-5, 1986]. Kurgan, 1986, pp. 36-38. (in Russian)

23. Kochutina L.N., Kudriavtseva I.P., Chumasov E.I., Svetikova K.M. Izmeneniia nervnykh provodnikov i ikh kontsevykh apparatov v myshtsakh i kozhe pri bolshikh odnoetapnykh udlineniiakh konechnosti po G.A. Ilizarovu [Changes of nerve conductors and their terminal apparatus in muscles and skin in case of large one-stage limb lengthenings according to G.A. Ilizarov]. Arkhiv Anatomii, Gistologii i Embriologii, 1990, vol. 98, no. 4, pp. 24-31. (in Russian)

24. Kudriavtseva I.P., Safonova G.D., Berdiugin K.A. Reaktsiia nervnykh struktur na dozirovannoe rastiazhenie tkanei pri udlinenii konechnosti [Response of nerve structures to graduated tissue stretching during limb lengthening]. Fundamentalnye Issledovaniia, 2014, no. 10-2, pp. 416-419. (in Russian)

25. Iastrebov A.P., Osipenko A.V. Sistema krovi i regeneratsiia kostnoi tkani [Blood system and bone tissue regeneration]. Sverdlovsk, Izd-vo Ural. Un-ta, 1990, 124 p. (in Russian)

26. Osipenko A.V., Chereshnev V.A. Immunobiologicheskie mekhanizmy regeneratsii tkanei [Immunobiological mechanisms of tissue regeneration]. Ekaterinburg, Izd-vo Ural. Un-ta, 1997, 129 p. (in Russian)

27. Bazarnyi V.V., Makarova E.B., Mamaev V.I. Otsenka effektivnosti immunoreabilitatsii pri udlinenii konechnosti [Evaluation of the effectiveness of immune rehabilitation when limb lengthening]. Tez. dokl. 2 mezhdunar. simp. "Reabilitatsiia immunnoi sistemy" [Proceedings of the $2^{\text {nd }}$ International Symposium "Rehabilitation of the Immune System"]. Tskhaltubo, 1990, pp. 152. (in Russian)

28. Mamaev V.I. Rannee prognozirovanie sostoianiia kosteobrazovaniia pri udlinenii kostei [Early prediction of bone formation condition when bone lengthening]. Ortopediia, Travmatologiia i Protezirovanie, 1984, no. 4, pp. 32-35. (in Russian)

29. Mamaev V.I. Prognozirovanie iskhodov operativnogo lecheniia bolnykh s posledstviiami perelomov dlinnykh trubchatykh kostei: monografiia 
[Prediction of the outcomes of surgical treatment of patients with the consequences of fractures of long tubular bones: a monograph]. Ekaterinburg, Chaklin UNIITO, 2015, 173 p. (in Russian)

30. Giulnazarova S.V., Kuznetsova O.A. Ossein-gidroksiapatitnyi kompleks v lechenii bolnykh s psevdoartrozami bedra i kostei goleni, oslozhnennymi sistemnym osteoporozom [Ossein-hydroxyapatite complex in treatment of patients with pseudoarthroses of the femur and leg bones, complicated by systemic osteoporosis]. Vestnik Travmatologii i Ortopedii im. N.N. Priorova, 2006, no. 2, pp. 21-24. (in Russian)

31. Trifonova E.B., Kuchiev A.Iu. Effekt giperbaricheskoi oksigenatsii pri immobilizatsionnom osteoporoze v eksperimente [Effect of hyperbaric oxygenation in immobilization osteoporosis experimentally]. Materialy pervogo sezda travmatologov-ortopedov uralskogo federalnogo okruga 1-3 iiunia 2005 g. "Vysokie tekhnologii v travmatologii i ortopedii: organizatsiia, diagnostika, lechenie, reabilitatsiia, obrazovanie" [Proceedings of the $1^{\text {st }}$ Congress of traumatologists-orthopedists of the Ural Federal Region, June 1-3, 2005, "High Technologies in Traumatology and Orthopaedics: organization, diagnosis, treatment, rehabilitation, education”]. Ekaterinburg, Avtograf, 2005, pp. 282-283. (in Russian)

32. Burmatova A.Iu., Trifonova E.B., Ganzha A.A. Osobennosti markerov osteogeneza pri primenenii metallofiksatorov s DLC-pokrytiem u patsientov $\mathrm{s}$ immobilizatsionnym osteoporozom [The peculiar properties of osteogenesis markers when using metal fixators with DLC-coating in patients with immobilization osteoporosis]. Genij Ortopedii, 2015, no. 3, pp. 100-102. (in Russian)

33. Serebrennikov N.A. Ustroistvo N.A. Serebrennikova dlia repozitsii i fiksatsii kostei taza pri perelomakh [N.A. Serebrennikov's device for reposition and fixation of pelvic bones in fractures]. Author's license no. 563968 SSSR, 1975. (in Russian)

34. Kutepov S.M., Mineev K.P., Stelmakh K.K., Shlykov I.L. Apparat dlia osteosinteza perelomov tazovykh kostei [A device for osteosynthesis of pelvic bone fractures]. Patent RF no. 1811386, A61B 17/60, 1989. (in Russian)

35. Kutepov S.M., Mineev K.P., Stelmakh K.K. Anatomo-khirurgicheskoe obosnovanie lecheniia tiazhelykh perelomov kostei taza apparatami vneshnei fiksatsii [Anatomic-and-surgical grounding of treating severe pelvic bone fractures with external fixators]. Ekaterinburg, Izd-vo Ural. Un-ta, 1992, 160 p. (in Russian)

36. Kutepov S.M., Novitskaia N.V., Mineev K.P., Stelmakh K.K., compilers. Lechenie perelomov kostei taza apparatami vneshnei fiksatsii: metod. rek. [Treatment of pelvic bone fractures with external fixators: a technique manual]. Sverdlovsk, 1991, 13 p. (in Russian)

37. Mineev K.P., Stelmakh K.K. Lechenie tiazhelykh povrezhdenii taza i pozvonochnika [Treatment of severe involvements of the pelvis and spine]. Ulianovsk, Simbirskaia Kniga, 1996, 182 p. (in Russian)

38. Runkov A.V., Shlykov I.L. Ustroistvo vneshnei fiksatsii dlia lecheniia perelomov tazovykh kostei [A device for external fixation for treating pelvic bone fractures]. Patent RF 2000125394, A61B 17/66, 2000. (in Russian)

39. Runkov A.V., comp. Chreskostnyi osteosintez taza i vertluzhnoi vpadiny: metod. rek. [Transosseous osteosynthesis of the pelvis and acetabulum]. Ekaterinburg, 2001, 23 p. (in Russian)

40. Runkov A.V., Shlykov I.L., Bliznets D.G., Bogatkin A.A., compilers. Maloinvazivnyi osteosintez povrezhdenii zadnikh otdelov taza: med. tekhnologiia [Little-invasive osteosynthesis of injuries of the posterior pelvic parts]. Ekaterinburg, 2011, 19 p. (in Russian)

41. Shlykov I.L., Runkov A.V. Apparat dlia zakrytogo ustraneniia stoikikh deformatsii tazovogo koltsa [The device for closed elimination of persistent deformities of the pelvic ring]. Patent RF no. 26186, A61B17/66, 2002. (in Russian)

42. Solomin L.N. Osnovy chreskostnogo osteosinteza apparatom G.A. Ilizarova [Basics of transosseous osteosynthesis with the Ilizarov fixator]. SPb., Morsar AB, 2005, 544 p. (in Russian)

43. Solomin L.N., ed. The Basic Principles of External Skeletal Fixation Using the Ilizarov and Other Devices. Ed. 2. Springer-Verlag Mailand, 2012, $1596 \mathrm{p}$.

44. Solomin L.N., ed. Osnovy chreskostnogo osteosinteza. Chastnye voprosy [Basics of transosseous osteosynthesis. Specific issues]. Ed. 2. M., BINOM, 2015, vol. 3, 560 p. (in Russian)

45. Lavrukov A.M., Tomilov A.B., Glazyrin D.I. Ustroistvo i sposob vneochagovogo osteosinteza pozvonochnika [The device and the way of the spine extrafocal osteosynthesis]. Patent RF no. 2115381, A61B 17/56, 1996. (in Russian)

46. Lavrukov A.M., Tomilov A.B. Sposob lecheniia povrezhdenii pozvonochnika, oslozhnennykh spinalnymi narusheniiami [The way of treating the spine injuries, complicated by spinal disorders]. Patent RF no. 2147844, A61B 17/56, 1996. (in Russian)

47. Lavrukov A.M., Tomilov A.B., Glazyrin D.I. Ustroistvo vneochagovogo osteosinteza pozvonochnika [The device for the spine extrafocal osteosynthesis]. Patent RF no. 4904, A61B 17/60, 1996. (in Russian)

48. Lavrukov A.M., Tomilov A.B. Osteosintez apparatom vneshnei fiksatsii u bolnykh s povrezhdeniiami i zabolevaniiami pozvonochnika [Osteosynthesis with an external fixator in patients with injuries and diseases of the spine]. Ekaterinburg, 2002, 208 p. (in Russian)

49. Lavrukov A.M., Tomilov A.B. Ustroistvo dlia stabilizatsii grudnogo i poiasnichnogo otdela pozvonochnika pri perelomakh [The device for stabilization of the thoracic and lumbar spine in case of fractures]. Patent RF no. 36199, A61B 17/00, 2003. (in Russian)

50. Lavrukov A.M., Tomilov A.B., Shalamov A.M. Ustroistvo dlia osteosinteza pozvonochnika [The device for the spine osteosynthesis]. Patent RF no. 43146, A61B 17/00, 2004. (in Russian)

51. Tomilov A.B., Plakhin E.V., Berdiugin K.A. Sposob ustraneniia zastarelykh deformatsii pozvonochnika [The way of elimination of the spine old deformities]. Patent RF no. 2345729, A61B 17/56, 2006. (in Russian)

52. Berdiugin K.A., Tomilov A.B. Sposob opredeleniia zadnego smeshcheniia pozvonka [The way of determination of the posterior displacement of the vertebra]. Patent RF no. 2358651, A61B 6/00, 2007. (in Russian)

53. Tomilov A.B., Mukhachev V.A., Plakhin E.V. Sposob khirurgicheskogo lecheniia spondiloliznogo spondilolisteza $v$ poiasnichnom otdele pozvonochnika [The way of surgical treatment of spondylolis spondylolisthesis in the lumbar spine]. Patent RF no. 2433798, A61B 17/70, 2010. (in Russian)

54. Khimich Iu.V., Tomilov A.B., Zelskii I.A. Sposob opredelenii pokazanii k vypolneniiu perednego mezhtelovogo spondilodeza pri khirurgicheskom lechenii bolnykh s kompressionno-oskolchatymi perelomami v nizhnem grudnom i poiasnichnom otdele pozvonochnika [The way of determining indications for performing the anterior interbody spondylodesis in surgical treatment of patients with compression comminuted fractures in the lower thoracic and lumar spine]. Patent RF no. 2445038, A61B 17/56, 2010. (in Russian)

55. Tomilov A.B., Plakhin E.V., Khimich Iu.V. Sposob stabilizatsii perelomov tel pozvonkov, oslozhnennykh osteoporozom [The way of stabilization of vertebral body fractures, complicated by osteoporosis]. Patent RF no. 2467715, A61B 17/56, 2011. (in Russian)

56. Tomilov A.B., Plakhin E.V., Khimich Iu.V., Zubkov E.A. Sposob intraoperatsionnogo kontrolia sostoianiia pozvonochnogo kanala pri zakrytoi repozitsii oskolchatykh perelomov tel pozvonkov [The way of intraoperative controlling the spinal canal condition in closed reposition of vertebral body comminuted fractures]. Patent RF no. 2474395, A61B 17/56, 2011. (in Russian)

57. Tomilov A.B., Khimich Iu.V., Plakhin E.V., Zubkov E.A. Sposob monosegmentarnoi transpedikuliarnoi stabilizatsii perelomov tel nizhnikh grudnykh i poiasnichnykh pozvonkov [The way of monosegmental transpedicular stabilization of the bodies of the lower thoracic and lumbar spine]. Patent RF no. 2485904, A61B 17/56, 2012. (in Russian)

58. Aktovaia rech G.A. Ilizarova «Nekotorye provodimye nami fundamentalnye issledovaniia i ikh obshchebiologicheskoe znachenie» (na Vsesoiuznoi Konferentsii s uchastiem inostrannykh spetsialistov, posviashchennoi 70-letiiu G.A. Ilizarova, 13-15 iiunia 1991 goda, g. Kurgan). Chast I [G.A. Ilizarov's Grand Speech "Some fundamental research performed by us and their general biological significance" (made at the National Conference with participation of foreign specialists devoted to G.A. Ilizarov's 70-th anniversary, June 13-15, 1991, Kurgan). Part I.]. Genij Ortopedii, 2015, no. 1, pp. 7-12. (in Russian)

59. Ilizarov G.A. Obshchebiologicheskoe svoistvo tkanei otvechat na dozirovannoe rastiazhenie rostom i regeneratsiei (effekt Ilizarova): Diplom 355 (SSSR) [General biological property of tissues to respond to graduated stretching with growth and regeneration (the Ilizarov effect): Diploma 355 (USSR)], 1985. (in Russian)

Received: 20.04 .2021

\section{Information about the authors:}

1. Sergei M. Kutepov, M.D, Ph.D., Professor, member-correspondent of RAS,

Ural State Medical University, Ekaterinburg, Russian Federation,

Email: Axr523@mail.ru

2. Stella V. Gulnazarova, M.D., Ph.D., Professor,

Ural State Medical University, Ekaterinburg, Russian Federation,

Email: Yand@pm.convex.ru 